\title{
Studies on an in-vitro Investigation of Anti Diabetic Property of a Hemiparasitic Taxa Dendrophthoe falcata (L.f.) Ettingsh (Loranthaceae)
}

\author{
Ayan Kumar Naskar ${ }^{1}$, Souradut Ray', Sanjukta Mondal Parui' ${ }^{2}$ and Amal Kumar Mondal ${ }^{1, *}$
}

\begin{abstract}
Ayan Kumar Naskar' ${ }^{1}$ Souradut Ray', Sanjukta Mondal Parui ${ }^{2}$ and Amal Kumar Mondal ${ }^{1, *}$

'Plant Taxonomy, Biosystematics and Molecular Taxonomy laboratory, UGC DRS-SAP, DBT-BOOST-WB Supported Department, Department of Botany \& Forestry, Vidyasagar University, Midnapore-721102, West Bengal, INDIA. ${ }^{2}$ Post Graduate Department of Zoology, Lady Brabourne College, Kolkata-700017, West Bengal, INDIA
\end{abstract}

\section{Correspondence}

\section{Amal Kumar Mondal}

Plant Taxonomy, Biosystematics and Molecular Taxonomy laboratory, UGCDRS-SAP, DBT-BOOST-WB Supported Department, Department of Botany \& Forestry, Vidyasagar University, Midnapore-721102, West Bengal, INDIA. E-mail: akmondal@mail.vidyasagar.ac.in History

- Submission Date: 08-12-2018;

- Review completed: 03-04-2019;

- Accepted Date: 18-04-2019.

DOI : 10.5530/pj.2019.11.111

Article Available online

http://www.phcogj.com/v11/i4

\section{Copyright}

(C) 2019 Phcogj.Com. This is an openaccess article distributed under the term of the Creative Commons Attribution 4.0 International license.

\begin{abstract}
Dendrophthoe falcata (L.f.) Ettingsh, belong to the family Loranthaceae an unique hemiparasitic taxon, spreads almost all the entire forest in South West Bengal. It is generally stem hem parasitic taxa and habitat mostly on aerial part of host plant having strong in spite of common root system. It is depend on the host plant for mainly water and to some extend carbon. It synthesizes its own food. The haustoria have penetrated to the vascular bundle mainly in the xylem tissue of the host plants. It has numerous medicinal values with a long history of its use in Chinese traditional medicines. Objectives: The present work deals with the anti-diabetic property medicinal aspect. Methods: The leaves extract mixed with the amylase enzyme then add the starch solution and allow the reaction for few minutes after that the reaction mixture interrupted with DNS. Results: The responsible enzyme i.e. Alpha-amylase breaks the large starch molecules which produces free glucose and simultaneously increases the blood sugar level and as a result hyperglycemia occurs. In this experiment increase the concentration of leaves extract which has decreased the activity of this potent enzyme. Conclusions: This study also reveals that, the plant's leaves extracts have inhibitory activity on this key enzyme viz. alpha amylase which is very crucial data for drug preparation and other research purposes. Key words: Dendrophthoe falcata, Loranthaceae, Alpha-amylase, Medicinal value.
\end{abstract}

\section{INTRODUCTION}

There are just $1 \%$ hemiparasitic taxa present in world vegetations. Among them the taxon Dendrophthoe falcata (L.f.) Ettingsh holds the major portion. This plant taxa is distributed throughout the natural forest vegetation of South West Bengal, mainly on the aged plants. As per our investigation, it was observed that, it is a rare plant in the forest. As this plant born on the rough surface bark of the host trees, dispersal of this seeds mainly occurred by sunbirds, as a result less than $50 \%$ successful rate of germination take place. Their abundance is very less in nature for this reason they shows camouflage for survival. The recognition or finding out of this plant is very laborious work because they look like a branch of the host trees. The leaf of this plant is green in color, wavy, thick, exstipulate, margin of the leaf reddish in color. The bark of stem is brown in color, uniformly distributed lenticels; slightly rough in texture, types of fruit is berry, zygomorphic flower (Figures 1a-d.).

There are many different types of human diseases found in our social life; Diabetes mellitus is one of them. This disease is chronic, severe characterized by hyperglycemia, due to improper regulation of insulin hormone. ${ }^{1}$ To prevent hyperglycemia or diabetes there is one way, to keep glucose level near to normal as much as possible in the blood. The non-pharmacological and pharmacological both approaches can manage diabetes. The non- pharmacological approaches to resist diabetes are exercise; diet control, surgery etc. alongside pharmacological approaches includes the use of drugs (insulin) or oral hypoglycemic agents. These remarkable anti diabetic drugs are not only costly but also associated with lots of side effects. ${ }^{1,2}$ Therefore, devoid of side effect and low-cost drugs are searched by the scientist from a long while. Interestingly, some plants are now identified to cure this lifelong disorder. One of them is Dendrophthoe falcata, hemi-parasitic taxa (Figure 1) which is available in the natural forest vegetation of South west-Bengal on a different host plants (Table 1). However, the responsible active molecules to cure diabetes from this plant have not been isolated till now. Many works had also been reported on the pharmacological activities such as antihypertensive, anti-epileptic and effects of immune stimulants. ${ }^{3,4}$

Alpha-amylase is the major form of amylase found in humans and other mammals. This enzyme cuts off alpha-bonds of large sugar molecules (Figure 2). This enzyme is found in plants (barley), Ascomycotina or Basidiomycotina fungus and bacteria (Bacillus sp.). Our human saliva also contains amylase enzyme which is digests the food initially. Foods that contain high amount of starch (rice, potato), or slightly sweet in test, when they are chewed in the mouth, amylase secretion is started and breaks down some of starch into sugar in our mouth. The pancreas also synthesizes alpha amylase to hydrolyze starch from dietary materials into mono, di and tri-saccharides 


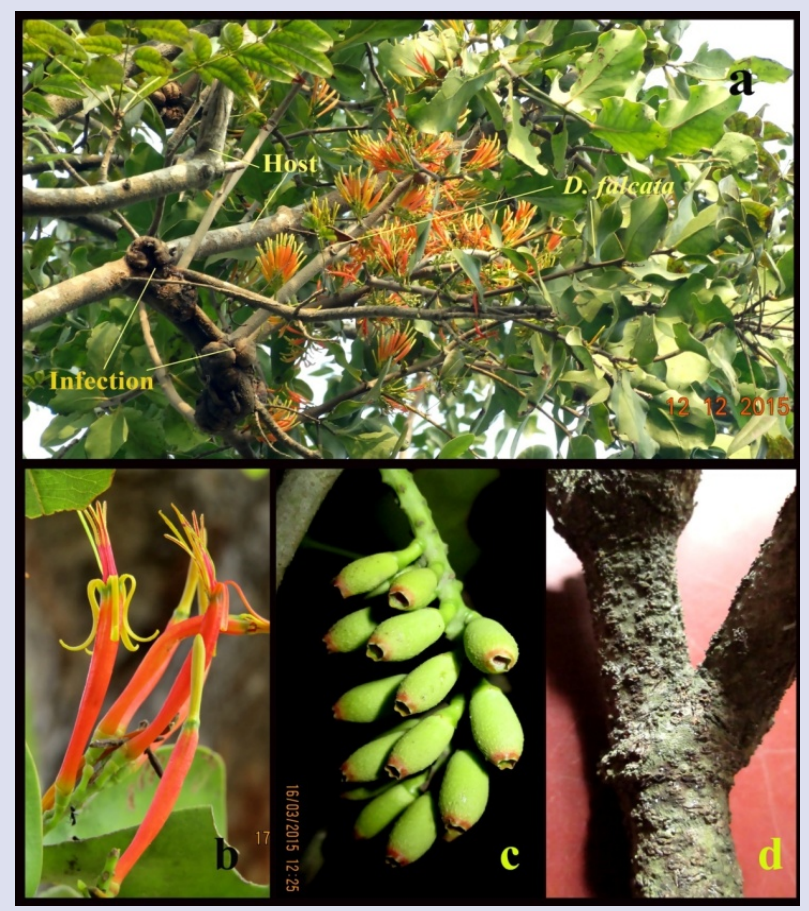

Figure 1: Habitat of Dendrphate falcata.

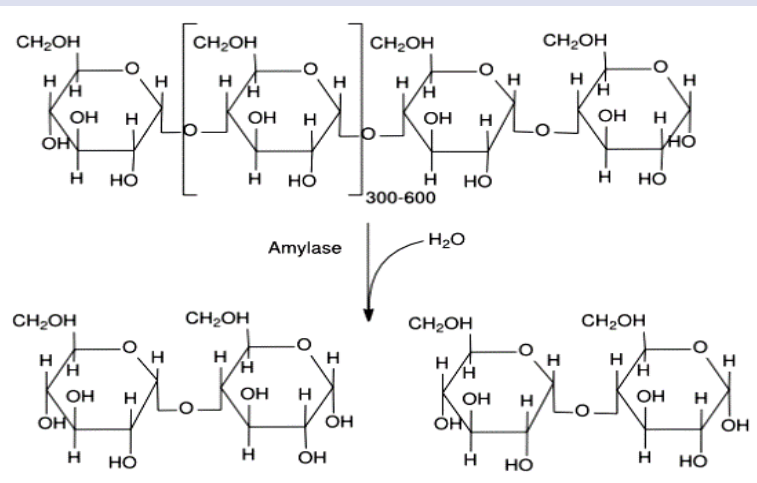

Figure 2: Mechanism of Alpha-amylase.

Table 1: Host plants of Dendrophthoe falcata.

\begin{tabular}{|c|c|c|c|}
\hline Sr. No. & Botanical name & Common name & Family \\
\hline 1. & Careya arborea Roxb. & Wild guava & Lacythidaceae \\
\hline 2. & Bombax ceiba $\mathrm{L}$ & Cotton tree & Malvaceae \\
\hline 3. & Shorea robusta Roth. & Sal & Dipterocarpaceae \\
\hline 4. & Terminalia catappa Linn. & Indian Almond & Combretaceae \\
\hline 5. & Lagerstroemia speciosa (L.) Pers. & Jarul & Lythraceae \\
\hline 6. & Toona serrata M. Roem. & Chinese Mahogany & Meliaceae \\
\hline 7. & Swietenia macrophylla king. & Mahagoni & Meliaceae \\
\hline 8. & Tectona grandis L.f. & Teak & Lamiaceae \\
\hline 9. & Swietenia mahagoni (L.) Jacq. & Bara Mahagoni & Meliaceae \\
\hline 10. & Aegle marmelosa Linn. & Beal, golden apple & Rutaceae \\
\hline 11. & Madhuca longifolia (Konig) J.F.Macbr. & Mahua & Sapotaceae \\
\hline 12. & Ficus religion $\mathrm{L}$. & Bo-tree. Peepal & Moraceae \\
\hline 13. & Albizia lebbeck (L.) Benth. & Siris & Leguminaceae \\
\hline 14. & Terminalia arjuna (Roxb.) Wight and Arn. & Aurjun & Cmbretaceae \\
\hline 15. & Ficus hispida $\mathrm{L}$. & Dumur & Moraceae \\
\hline 16. & Limonia acidissima $\mathrm{L}$. & Wood apple & Rutaceae \\
\hline 17. & Magnifera indica L. & Mango & Anacardiaceae \\
\hline 18. & Melia azedarach L. & Mahaneem & Meliaceae \\
\hline
\end{tabular}


which supply the body energy. The objectives of my study is therefore determining the Inhibitory effect of Dendrophthoe falcata on a-amylase enzyme.

\section{Distribution of these Taxa}

Dendrophthoe falcata is also known as "Vanda" in the Indian Ayurvedic System of Medicine. D. falcata is a perennial woody parasitic plant. This plant is widespread throughout India (Figure 3), including Andaman and Nicobar Islands, Srilanka, Nepal, Bhutan, Indi-china, Thailand, tropical Australia, Bangladesh, Malaysia and Myanmar. ${ }^{5}$

\section{MATERIALS AND METHODS}

Dendrophthoe falcata leaves are selected for present study. The sample were collected from the difference natural, undisturbed forests area or rural area of south west Bengal like Mednapore (Salboni forest, Arabari forest, Hoomgarh forest), Purulia (Ajodhya hills), Bankura (Sarenga jungle) etc. during January to March 2017.

Plant fresh material was dried under sunlight up to 4-5days then grind with the help of motor and pestel to make fine powder and after that homogenized with water and boiled for $10 \mathrm{~min}$. The extract was filtered and then centrifuged. The supernatant was used for determination of enzyme inhibitory property. Assay of a-amylase inhibitory property: Plant extract $(0.1 \mathrm{ml})$ was incubated with $0.2 \mathrm{ml}$ of properly diluted enzyme for $20 \mathrm{~min}$ at $37^{\circ} \mathrm{C}$ temperature. Then $0.1 \mathrm{ml}$ of starch solution was added to the reaction mixture and incubated for $3 \mathrm{~min}$ at $37^{\circ} \mathrm{C}$ temperature. The enzyme reaction mixture was interrupted by the addition of $0.2 \mathrm{ml}$ Dinitrosalicylic (DNS) acid and heated for $5 \mathrm{~min}$ in boiling water. Then the tube containing the mixture was cooled under running tap water. Then $4 \mathrm{ml}$ water was added and optical density of the solution was determined by spectrophotometer at $540 \mathrm{~nm}$. A blank mixture was prepared in same manner without adding enzyme in the mixture, percentage inhibition of enzyme activity was measured.

\section{RESULTS}

The plant extract showing Anti-diabetic activity has an important role in inhibiting the glucose level thus providing protection to human against hyperglycemia. This study is carried out to evaluate the antidiabetic activity of aqueous extract of the leaves of $D$. falcata. ${ }^{6}$ In our experiment different conc. of plant extracts are applied on the solution mixture which contain alpha-amylase enzyme, starch and DNS. Measure the Optical Density of the mixture by UV Spectrophotometer (UV-1800 Shimadzu) and a significant result we found (Table 2).

The result of the experiment is given in following tabulated form and graphical representation of the data present in Figure 4.

The data presented here indicate that aqueous extract of $D$. falcate possesses significant amylase inhibition activity in in-vitro condition. DNS or dinitrisalisilic acid is a chemical compound that binds to the glucose (Reducing sugar), it cannot bind with the non-reducing sugar. ${ }^{7,8}$

In my experiment, when plant extract, enzyme and starch solution were incubated for $3 \mathrm{~min}$ at $37^{\circ} \mathrm{C}$, enzyme break down the starch and produced glucose and side by side DNS react with this free glucose and give ANS which shows maximum absorbance at $540 \mathrm{~nm} .{ }^{9}$ But when we increase the plant extract concentration, the enzyme amylase

Table 2: O.D values of the DNS in respect to different plant concentration.

\begin{tabular}{|cc|}
\hline Concentration of plant extract $(\mathrm{mg} / \mathrm{ml})$ & OD value \\
\hline 100 & 1.895 \\
200 & 1.621 \\
300 & 1.425 \\
400 & 1.329 \\
500 & 1.286
\end{tabular}

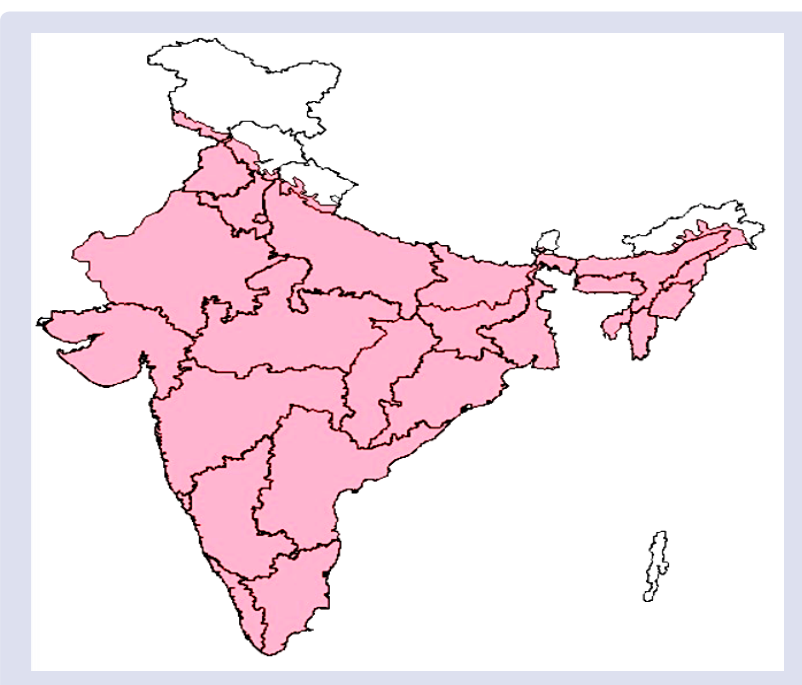

Figure 3: Distribution of $D$. falcata in India. (Source: envis.frlht. org/maps).

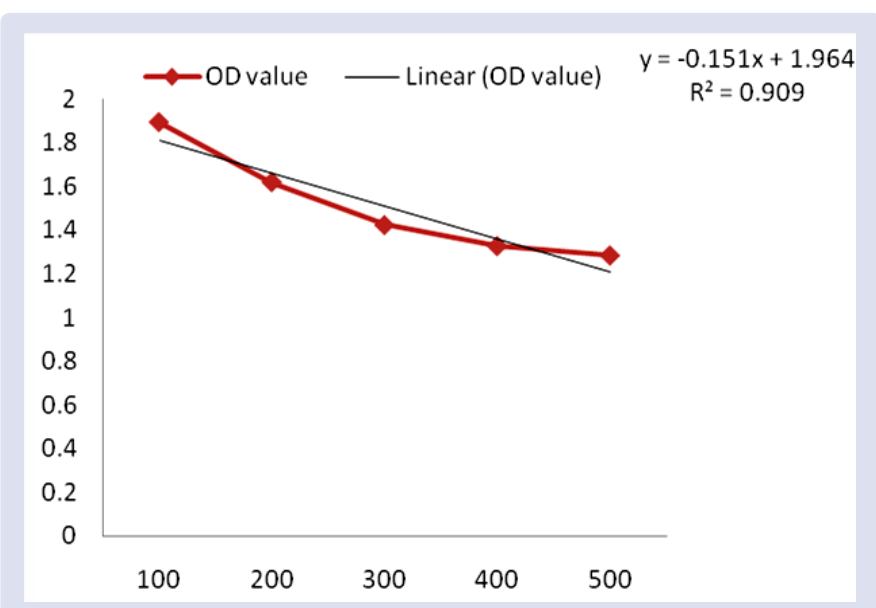

Figure 4: Amylase inhibitory activity of different concentration of plant extract.

inhibited slowly as a result production of free glucose is decreased and ANS production is also decreased slowly in the reaction mixture that's why the OD value decreased slowly. It represents that the plant extract having a alpha amylase inhibitory properties.

\section{CONCLUSION}

For complementary or synergistic effects of herbal products, it may be prepare with the help of a single herb or combination of multiple herbs. Sometime animal's product and minerals are included to the herbal products for formulating the traditional medicine. It will be sold in market either in raw plants or extraction of the plant's part. Although raw extraction of the various plant's parts have medicinal importance but modern drugs come in market after comprehensive investigation on bioactivity, pharmaco-therapeutics, mechanism of action and toxicity and after proper standardization and clinical trials. Present study shows that the plants Dendrophthoe falcata have inhibitory activity of alpha amylase. Since alpha amylase is the one of the most important enzyme which mainly is responsible for hyperglycemia, by inhibiting its enzymatic activity with the above mentioned plant are having anti diabetic properties. From above plants, the drug-development programmer may be take response to develop modern drugs with the help of mastered chemical compound for that disease. Now time has to be changing, the use of that non-toxic plant that's having traditional 
medicinal value, development of modern drugs from these plants should be emphasized for the control of various diseases. In fact, time has come to make good use of centuries- old knowledge on plants through modern approaches of drug development. An extensive research and development work should be undertaken on these plants and its products for their better economic and therapeutic utilization.

\section{ACKNOWLEDGEMENT}

The DRS-SAP-I funded by UGC, New Delhi we are highly acknowledged. The work based on M. Sc. project work including DRS-SAP-I under the Co-ordinator of Prof A. K. Mondal FLS, FIAAT, Professor of Botany and proper discussion with Dr. S. Mondal Parui, HOD, Co-coordinator, P.G. Department of Zoology, Section Biochemistry, Lady Brabourne Collage, Kolkata. I am also thankful to all research scholars of Plant Taxonomy, Biosystematics and Molecular Taxonomy Laboratory for their valuable guidance and help throughout the study.

\section{CONFLICTS OF INTEREST}

None.

\section{REFERENCES}

1. Aguwa $\mathrm{CN}$. Therapeutic basis for clinical pharmacy in the tropics, (3rd ed.). Enugu. 2004.

2. Adeneye AA, Agbaje EO. Pharmacological evaluation of oral hypoglycemic and antidiabetic effects of fresh leaves of ethanol extract of Morinda lucida benth in normal and alloxan-induce diabetic rats. African Journal of Biomedic. 2008;11(1):65-71.

3. Pernossian A, Kocharan A. Pharmacological activities of phenyl propanoids of mistletoe (Loranthus parasiticus) sourced from different host trees. Bioresearch Journal. 2004;2(1):18-23.

4. Imafidon KE, Igbinaduwa P. Effects of dried powdered leaves of Loranthus bengwensis L. (African mistletoe) on blood pressure and electrolyte leves of normal and hypertensive rats. Global Journal Biotechnology Biochemistry. 2007;2(2):51-3.

5. Balakrishnan NP, Chakrabarty T, Sanjappa M, Lakshminarsimhan P, Singh P. Flora of India: BSI Kolkata. 2012;23:3

6. Allekutty NA, Sriniwasan KK, Gundu RP, Udupa AC, Keshawamurthy KR. Diuretic and antilithiatic activity of Dendrophthoe falcata. Fitotherapia. 1993;64(5):32531.

7. Moshrafuddin A. Medicinal Plants. MJP Publishers, Chennai. 2010.

8. Nadkarni's KM. Indian Materia Medica. Bomby Popular Prakashan. 1976.

9. Pattanayak SP, Mazumder PM. Effect of Dendrophthoe falcata (L.f.) Ettingsh on female reproductive system in Wistar rats: a focus on antifertility efficacy Contraception: An International Reproductive Health Journal. 2009;80(3):314 20.

\section{GRAPHICAL ABSTRACT}

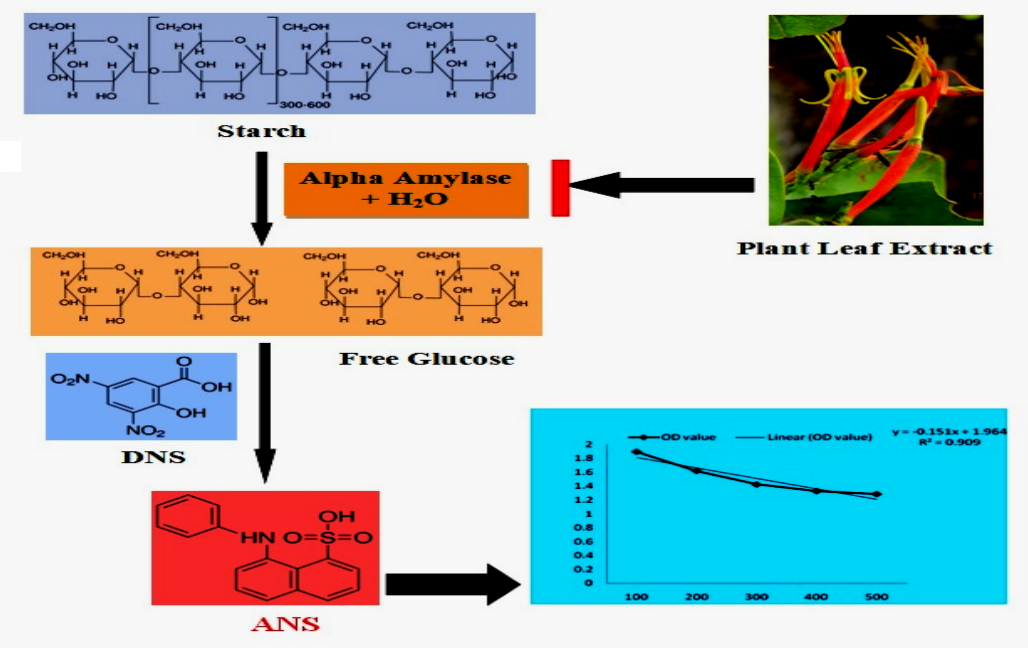




\section{ABOUT AUTHORS}

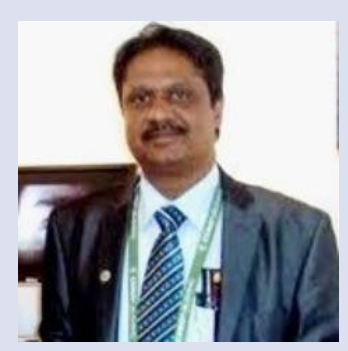

Professor (Dr.) Amal Kumar Mondal is a Bonafide faculty member of Botany and Coordinator of UGC-DRS-SAP-II, New Delhi \& DBT-BOOST, West Bengal of the Department of Botany \& Forestry, Vidyasagar University, West Bengal, India. He was elected as a Fellow of Linnaean Society (FLS) of London and Indian Association for Angiospermic Taxonomy (FIAAT). He completed his B.Sc. Degree in Botany from Suri Vidyasagar College (Under University of Burdwan) in 1989 and M.Sc. from University of Burdwan with Taxonomy of Angiosperm as a special paper in 1991. After that he completed his Bachelor of Education in Science (B.Ed. Science) from the same university in 1992-1993. He qualified GATE \& CSIR-NET examination (JRF-CSIR) in 1991 and completed his Ph.D. degree from Visva-Bharati University (1992-1997). He first joined as a lecturer in the Post Graduate Department of Botany, Darjeeling Government College in September, 1997. After that he was transferred to Barasat Government. College in December, 2001 and finally joined Vidyasagar University in 2006. He has 30 years of research experience and 26 years of teaching experience at both undergraduate and Post Graduate level. He has published more than 200 research papers, 50 popular scientific articles in different international and national journals, Science Magazines \& daily Newspaper. He has published 30 chapters in the different national and international reputed edited books. Eleven students have already been awarded their Ph.D. under his supervision. He has successfully completed 6 UGC Major \& Minor Research Projects, UGC-Non-SAP RSMFS Fellowship etc. He has received more than 12 different prestigious awards viz. Adarsh Vidya Saraswati Rashtriyo Puraskar, National Award, Distinguished Faculty Award in Science for the contribution and achievement in the field of Botany (Plant Sciences), Taxonomy and Systematics etc. He also received the most prestigious UGCResearch Award in the year 2004. He has published a Text book entitled "Advanced Plant Taxonomy" from New Central and revised edition will be published in the end of 2019 for both Undergraduate and Post Graduate level. He is the Life Member of different reputed Academic bodies, Societies etc. and member of different academic bodies in his home University as well as different Universities and Post Graduate Colleges.

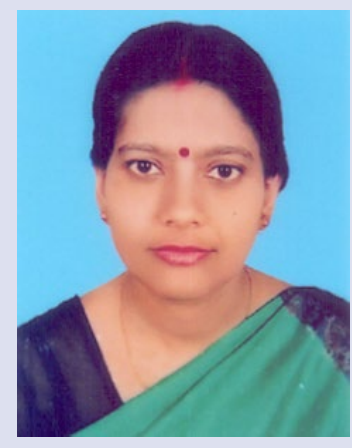

Dr. Sanjukta Mondal (Parui) is Associate Professor of Zoology, West Bengal Education Service (WBES), and Head of the Department of Post Graduate Department of Zoology, Lady Brabourne College under Calcutta University. She completed her B.Sc. Degree in Zoology from S.G. Women's College, Rourkela under Sambalpur University in 1990 and M.Sc. from School of Life Sciences, Sambalpur University in 1992. She qualified GATE \& CSIR-NET examination (JRF-CSIR) in 1993 and was awarded Ph.D. degree from Visva-Bharati University in 2000. She first joined as a Lecturer in the Post Graduate Department of Zoology, Darjeeling Government. College in July, 1998. After that she also served Barasat Government College before being transferred to lady Brabourne College. She has 24 years of research experience and 20 years of teaching experience. She has published more than 98 research papers, 31 popular scientific articles, 3 Book Chapters in different international and national journals. Two students have already been awarded their Ph.D. under her Supervision. She has successfully completed 4 UGC Major \& Minor Research Projects. She received the UGC Research Award in 2004, for her Research Contribution in the field of Biochemistry and Molecular Biology. She is an Editorial Board Member of the Journal 'ARANYA' (Natural Wild Life Conservation Society) and also Life member of 'Zoological Society', 'Indian Science Congress', and 'NESA'.

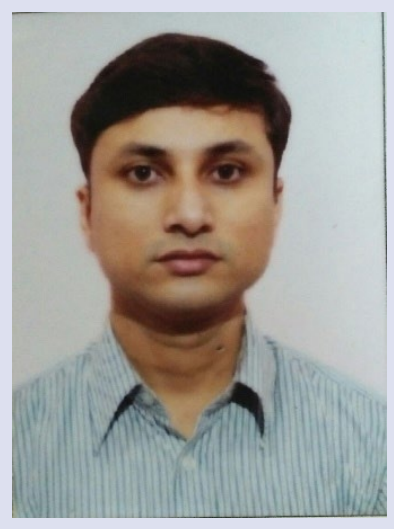

Mr. Souradut Ray is a Project Fellow under UGC-DRS-SAP-I (2012-2016) in the Department of Botany \& Forestry, Vidyasagar University, Midnapore. He completed his B.Sc. degree in Botany from Krishnath Nath College under Kalyani University in 2007. After that he successfully qualified the entrance examination of M.Sc. at Calcutta University and completed his M.Sc. degree in 2009 with specialization Pharmacognosy. In 2012 he joined as a Research Fellow after successfully qualifying the RET examination at the Plant Taxonomy, Biosystematics \& Molecular Taxonomy Laboratory, Department of Botany \& Forestry, Vidyasagar University under the Principal supervision of Professor Amal Kumar Mondal and Co-supervision by Professor N.K.Verma, Retired Professor, Department of Botany \& Forestry, Vidyasagar University.. He has 2 years experience in 'Village Eco-restoration Project' under West Bengal Biodiversity Board. He has more than 7 Publications in different International and National Journals. He also attended more than 10 National level Seminars/ Workshops. 


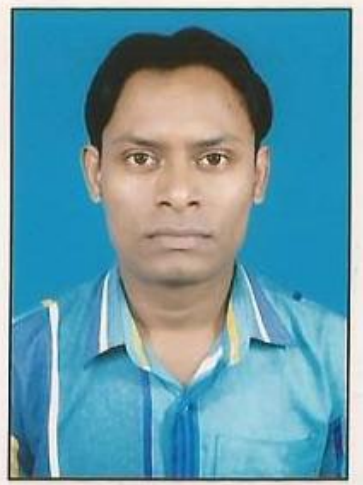

Mr. Ayan Kumar Naskar is a Project Fellow under UGC-DRS-SAP-II (2018-2023) in the Department of Botany \& Forestry, Vidyasagar University, Midnapore. He completed his B.Sc. degree in Botany (H) from Uluberia College under Calcutta University in 2013. After that he successfully qualified the entrance examination of M.Sc. at Vidyasagar University and completed his M.Sc. degree with special paper 'Advance Plant Taxonomy' in 2015. In 2016 he joined as a Research Fellow after successfully qualifying the RET examination at the Plant Taxonomy, Biosystematics \& Molecular Taxonomy Laboratory, Department of Botany \& Forestry, Vidyasagar University under the supervision of Professor Amal Kumar Mondal. Recently he has published one Chapter of the Book entitled "Plants for Human Survival." He has also attended more than 10 National level Seminars/Workshops. He has 4 Research Publications in National and International Journals.

Cite this article: Naskar AK, Ray S, Mondal Parui S, Mondal AK. Studies on an in-vitro Investigation of Anti Diabetic Properties of a Hemiparasitic Taxa Dendrophthoe falcata (L.f.) Ettingsh (Loranthaceae). Pharmacog J. 2019; 11 (4):699-704. 